\title{
Identification and evaluation of suitable reference genes for gene expression analysis in rubber tree leaf
}

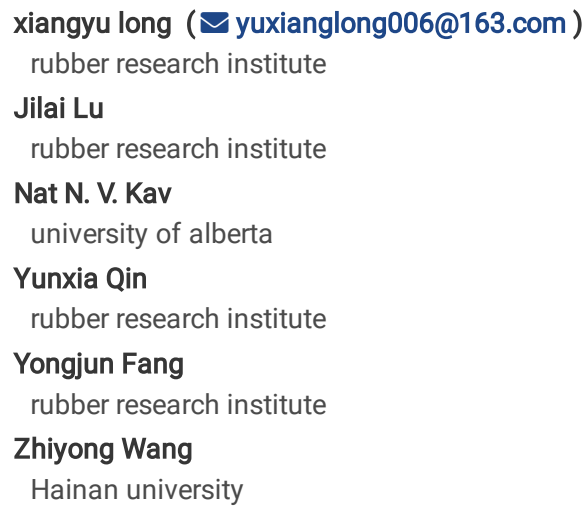

Version of Record: A version of this preprint was published at Molecular Biology Reports on February 4th, 2020. See the published version at https://doi.org/10.1007/s11033-020-05288-8. 


\section{Abstract}

Backgroud Gene expression profiling is increasingly applied to investigate molecular mechanisms for which, normalization with suitable reference genes is critical. Previously we have reported several suitable reference genes for laticifer samples from rubber, however, little is known about reference genes in leaf. Results The main objective of this current study was to identify some reference genes with stable expression patterns in leaf at various developmental stages, as well as during abiotic (temperature extremes) and biotic stresses. Gene expression profiling experiments in rubber tree leaf identified the ubiquitinproteasome system as having excellent potential as reference genes. Among a total of 30 tested genes investigated, 24 new (including 11 genes involved in the ubiquitin-proteasome system), 4 previously identified and 2 specific genes, were further evaluated using quantitative real-time PCR. Our results indicated that the new genes had better stability of expression when compared with others. For instance, an ubiquitin conjugating enzyme (RG0099) and three ubiquitinprotein ligases (RG0928, RG2190 and RG0118) expressed stably in all samples, and were confirmed to be suitable reference genes in rubber tree leaf in four different conditions. Finally, we suggest that using more than one reference gene may be appropriate in gene expression studies when employing different software to normalize gene expression data. Conclusion Our findings have significant implications for the reliability of data obtained from genomics studies in rubber tree and perhaps in other species.

\section{Background}

Gene expression profiling studies are widely used to investigate plant processes, including metabolic pathways, including regulatory networks that are crucial for plant growth \& development as well as in stress responses. These types of genomics-based investigation necessitate the use of appropriate reference genes to normalize gene expression data. Incorrect choice of reference genes in techniques such as real-time quantitative PCR (qRT-PCR), RT-PCR, Northern blotting, ribonuclease protection assay and gene chip can result in the misinterpretation of gene expression data [ 1-3]. An optimal reference gene should be stably expressed in various tissues and under different experimental conditions without being influenced by the experimental conditions used [ 4,5$]$. Common reference genes that are used to normalize gene expression data include 18S ribosomal RNA (18S rRNA), actin (ACT), glyceraldehyde-3-phosphate dehydrogenase (GAPDH), tubulin (TUB). However, various studies have indicated that they may be unsuitable as reference genes for normalization due to the effects of certain experimental conditions on their expression [6-8]. Many studies have been conducted to screen and identify new reference genes that show stable expression patterns and to determine the appropriateness of genes traditionally used as reference genes in specific species and experimental conditions [ 9-18].

In rubber trees (Hevea brasiliensis), natural rubber synthesis is the main metabolic activity in laticifers which are highly specialized cells that directly influence the yield of rubber [ 19]. Most studies in molecular biology, especially those using gene expression profiling, have paid close attention to rubber biosynthesis in laticifers [ 20-25]. Previously, we have evaluated the expression stability of 22 reference genes across abundant laticifer samples, including latex regenerations, hormone treatments, tappings, individual trees and genotypes of Hevea [26,27]. As mentioned earlier, the availability of reliable reference genes is critical for gene expression studies involving glycometabolism and hormone regulation of rubber biosynthesis in laticifers [ 22, 25, 28, 29].

Leaves as photosynthetic tissues (sources) provide the nutrition and energy for rubber biosynthesis [ 20]. In recent years, more and more attention has been paid to leaf research, including leaf development and disease-resistance. For instance, due to the fact that sucrose is the precursor for rubber biosynthesis, enzymological characterization and gene expression of sucrose metabolizing enzymes were systematically investigated to understand the regulation of sucrose metabolism during leaf development in the rubber tree [30]. In addition, leaf development has been widely studied within the context of leaf diseases, especially South American leaf blight (SALB), which directly influences rubber yield, [ 31, 32]. However, as mentioned previously, little is known about reliable reference genes in leaves in order to normalize gene expression data in leaves.

In this study, two transcriptome sequencing profiles of leaves were screened for appropriate reference genes [ 32, 33]. The expression of selected genes was verified by qRT-PCR under four different experimental conditions. Our results demonstrated that the ubiquitin-proteasome system had significant potential as reference gene in rubber leaf tissues. Another important finding from this study was that the choice of algorithm used to normalize gene expression data had a significant impact on the results. Our findings are discussed within the context of using the appropriate reference gene to normalize gene expression data, which has the potential to significantly affect results from gene expression profiling studies.

\section{Methods}

\section{Plant materials and treatments}

The Hevea cultivars in Hainan Province, Reyan7-33-97 (synonym: CATAS7-33-97 or RY7-33-97), were provided by the experimental plantation of CATAS (Chinese Academy of Tropical Agricultural Sciences, Danzhou, Hainan, China). One-year-old tissue cultured Reyan7-33-97 plants were selected for the collection of six developmental stages of leaf, including bud, bronze, color-change, pale-green, bright green (mature) and aging. In addition, 6-month-old tissue cultured Reyan7-33-97 plants were used for our biotic and abiotic stress experiments. For the biotic stress experiments, leaves were collected at $0 \mathrm{~h}, 12$ h, 24 h, 48 h, 3d and 5d after inoculating with the pathogenic fungus Corynespora cassiicola HccYN57. In the case of abiotic stress experiments, plants were treated with low $\left(4^{\circ} \mathrm{C}\right)$ and high $\left(45^{\circ} \mathrm{C}\right)$ temperatures in a growth cabinet with relative humidity of $75-90 \%$ and lighting of 16 hours per day, and their leaves were collected at $0 \mathrm{~h}, 3 \mathrm{~h}, 6 \mathrm{~h}, 9 \mathrm{~h}, 12 \mathrm{~h}$, and $24 \mathrm{~h}$ after the imposition of stress. All collected leaves were frozen and stored at $-70^{\circ} \mathrm{C}$ until they were used for RNA isolation.

\section{Total RNA isolation and cDNA synthesis}


Total RNA was extracted from leaf tissue using PureLink ${ }^{\text {TM }}$ Plant RNA Reagent (Thermo, USA) following the manufacturer's instructions. Genomic DNA was removed after digestion with DNase 1 (Thermo, USA) also according to manufacturer's protocols. RNA concentration and its integrity were determined using a spectrophotometer NanoDrop 2000 and using agarose gel electrophoresis. cDNA was synthesized by reverse transcription using PrimeScript ${ }^{\text {TM }}$ RT reagent Kit with gDNA Eraser (Perfect Real Time, Takara, Japan), as per the manufacturer's protocols. Newly synthesized cDNA was diluted 10 fold for use in qRT-PCR experiments.

\section{Collecting candidate reference genes from transcriptome sequencing data}

In this study we focused on two reported transcript profiles for screening new candidate reference genes from rubber tree leaf at developmental stages (bronze, color change, pale-green and bright green) as wells as under temperature stress (high and low temperature) [ 32, 33]. Genes were selected as candidate reference genes if they showed reads per kilobase per million mapped reads (RPKM) fold change $<1.5$. Functional annotations and classifications of these genes were carried out using BLAST NCBI (https://blast.ncbi.nlm.nih.gov/Blast.cgi) and KEGG (https://www.genome.jp/kegg/pathway.html). Finally, 24 genes were chosen as new candidate reference genes to further validate expression stability using qRT-PCR.

\section{Primer design and qRT-PCR assays}

A total of 30 tested primer pairs were designed using the OligoAnalyzer web service (https://sg.idtdna.com/calc/analyzer), for the 24 new candidate reference genes, 4 previously used reference genes (Eukaryotic translation initiation factor 1A, elF1Aa; DEAD/DEAH box helicase, RH8; Ubiquitin-protein ligase, UBC2a and UBC2b) and 2 specific genes (ATP citrate lyase, RG1588154 and RG65560). PCR reactions were performed on a CFX96 Touch Real-Time PCR (Bio-Rad, USA), using the SYBR® Premix Ex TaqTM II (Perfect Real Time, TaKaRa, China). Each sample had three technical replicates, and the PCR reaction conditions were as previously described [ 27]. Data analysis was carried out using CFX Manager (Bio-Rad, USA), including the melting curve, quantification cycle values $(C t)$, PCR efficiency $(E)$ and correlation coefficients $\left(R^{2}\right)$.

\section{Data analysis}

The arithmetic mean, geometric mean, standard deviation and variation coefficient of quantification cycle values (Ct) were calculated and statistically analyzed using SPSS 13 (http://www.spss.com/). Four software with different algorithm, NormFinder, GeNorm, Bestkeeper and comparative delta Ct method, were used to analyze expression stability of reference genes, according to their instructions (RefFinder, https://reffinder.net/) [ 34-37]. Minitab 15 software (http://www.minitab.com/) was used to calculate the Pearson correlation coefficients for ranking results from four different evaluation algorithms.

\section{Results}

\section{Selection of candidate reference genes}

In this study, we used two previously reported [32,33] transcript profiles of rubber tree in order to select new candidate reference genes from leaf, including developmental stages (bronze, color change, pale-green and bright green) and abiotic stress (high and low temperature). When the gene expression data was analyzed for those genes where the change in expression less than 1.5 fold, we observed that there were 3,673 and 1,987 transcripts that could be selected from the two experiments, respectively. Among those, 82 genes were observed to exhibit little or no change of expression in both experiments (Fig. S1). In order to identify additional suitable candidate genes, BLASTx was used for gene functional annotation against NCBI and KEGG databases, which resulted in 62 annotated genes involved in five pathways (Table S1). Within those pathways, the genetic information processing pathway was the most represented (39 genes, $47.56 \%$ ), and included transcription machinery (16 genes, 19.51\%), ubiquitin system (13 genes, 15.85\%), membrane trafficking (6 genes, $7.32 \%)$, chromosome (3 genes, 3.66\%) and protein processing (1 gene, 1.22\%). Others that were represented included metabolism (11 genes, $13.41 \%)$, environmental information (6 genes, $7.32 \%$ ), organismal system (3 genes, 3.66\%) and cellular processes (3 genes, 3.66\%) (Fig. 1). These results provided us with the identities of several genes that could be further analyzed using qRT-PCR to narrow down those that may serve as reliable reference genes.

\section{Expression profiles of candidate reference genes}

Based on the expression and annotation results, 24 genes were selected as candidate reference genes which were involved in basic metabolic pathways or had the most stable expression in transcript profiles. These genes represented the transcription machinery ( 9 genes), ubiquitin system (11 genes), specific protein (1 gene), amino acid metabolism (1 gene), nucleotide metabolism (1 gene) and uncharacterized protein (1 gene). The identities of the genes selected for detailed characterization of expression profiles are provided in Table 1. In addition, 4 previously used reference genes (Eukaryotic translation initiation factor 1A, elF1Aa; DEAD/DEAH box helicase, RH8; Ubiquitin-protein ligase, UBC2a and UBC2b) and 2 specific genes (ATP citrate lyase, RG1588154 and RG65560) were analyzed in order to ascertain their ability to serve as reliable reference genes (Table 1). Thus, a total of 30 genes were evaluated for their expression stability in 60 leaf samples including various developmental stages, high and low temperature stress, and pathogen stress.

qRT-PCR results showed that the amplification efficiencies $(E)$ for these genes ranged from 0.85 to 1.05 , and the correlation coefficients $\left(R^{2}\right)$ ranged from 0.997 to 1.000 (Table 1). After removing missing and inconsistent data, the mean Ct value for each gene was calculated for all samples to determine expression levels (Table 2, Fig. 2). Wide ranges of Ct values from 19.56 to 36.97 across all samples were observed for the genes investigated (Table 2). The RG0140 gene had the most abundant transcripts with Ct values $23.71 \pm 2.05$ and, in contrast, the RG0544 gene had the lowest expression levels with Ct values 
31.73 \pm 1.89 . It was clear that there was approximately 200 -fold difference in expression levels between these two genes at either end of the expression spectrum. With respect to variation in levels of expression between different samples, the gene RG1039 exhibited the lowest variability (CV, 5.95) and the gene RG65560 was observed to be the most variable (CV, 11.15).

\section{Assessment of Delta Ct, BestKeeper, Normfinder and Genorm}

Four different software packages with different algorithms, Delta Ct [ 37], BestKeeper [ 34], Normfinder [ 35] and Genorm [ 36], were used to evaluate the expression data for the 30 genes in all samples. Our results suggested that Delta Ct, Normfinder and Genorm provided very similar results for gene expression, specifically the same ranking from 19 to 30 . Furthermore, these three software packages exhibited high correlation coefficients $\left(R^{2}\right)$, ranging from 0.9259 to 0.9829 further illustrating the fact that they generally yield similar results (Fig. 3). BestKeeper had the lowest $R^{2}$ ranging from 0.066 to 0.080 when compared with other software packages, which indicates an inconsistent ability to accurately calculate gene expression data (Fig. 3). In conclusion, among the software packages evaluated in this study, Delta Ct, Normfinder and Genorm provided more reliable quantification of gene expression when compared with BestKeeper.

\section{Expression stability of candidate reference genes}

Our results suggest that there were obvious differences in gene expression during different developmental stages, high and low temperature challenges as well as pathogen stresses for all the genes tested, when Delta Ct, Normfinder and Genorm were used for analysis of the data (Table 3). Based on ranking of expression stability, high and low temperature stress experiments were clustered together, indicating they have similar expression patterns (Fig. S2). Furthermore, in temperature stress experiments, the five most stable genes were RG0623, RG0099, RG1206, RG1293 and RG0470 in high temperature stress treatment, and rUBC2A, RG0427, RG0099, RG1200 and RG1121 in low temperature stress treatment (Table 3). In contrast, the expression of both RG0239 and RG0544 was unstable under temperature stress (Table 3). In disease stress, RG0677, RG1039, RG2190, RG0623 and RG0118 were found to be the most stably expressed genes, whereas RG1376, RG0544, RG1478, RG0470 and RG1206 were the least stable genes. Finally, during leaf development, RG0782 showed the most stability in expression, followed by rEIF1Aa, RG0427, RH8 and RG1121 and the genes RG1478, RG0544, RG1293, RG65560 and RG1206 exhibited lower stability of expression (Table 3).

Taken together, the gene expression data from our four experiments indicate that the genes RG0099, RG0427, RG0928, RG2190, RG0118, RG0677, rEIF1Aa, RG1121, RG0623 and RG0354 were the top ten most stable candidate reference genes whereas the genes RG1478, RG1588154, RG0544, RG1206 and RG65560 were the least stable (Table 3). In top ten stable genes, four experiments only shared one gene, RG0099, that was ranked $2^{\text {nd }}$ in high temperature stress, $3^{\text {rd }}$ in low temperature stress, and $6^{\text {th }}$ in developmental stages $\&$ disease stress (Fig. 4, Table 3 ). In contrast, RG0554 was considered to be unstable in expression, ranking $30^{\text {th }}$ in high temperature stress, $29^{\text {th }}$ in low temperature stress, $27^{\text {th }}$ in developmental stages and disease stress (Fig. 4, Table 3 ). Among the previously used four reference genes, rEIF1Aa showed a better stability of gene expression in all samples with an overall ranking of $7^{\text {th }}$. Two ATP citrate lyase genes, RG1588154 and RG65560, were identified to be the least stable, ranking as $27^{\text {th }}$ and $30^{\text {th }}$ respectively when all four experiments are considered.

\section{Reference}

1. Udvardi MK, Czechowski T, Scheible WR: Eleven golden rules of quantitative RT-PCR. The Plant cell 2008, 20(7):1736-1737.

2. Huggett J, Dheda K, Bustin S, Zumla A: Real-time RT-PCR normalisation; strategies and considerations. Genes and immunity 2005, 6(4):279-284.

3. Dheda K, Huggett JF, Chang JS, Kim LU, Bustin SA, Johnson MA, Rook GA, Zumla A: The implications of using an inappropriate reference gene for real-time reverse transcription PCR data normalization. Analytical biochemistry 2005, 344(1):141-143.

4. Bustin SA: Quantification of mRNA using real-time reverse transcription PCR (RT-PCR): trends and problems. Journal of molecular endocrinology 2002, 29(1):23-39.

5. Guenin S, Mauriat M, Pelloux J, Van Wuytswinkel O, Bellini C, Gutierrez L: Normalization of qRT-PCR data: the necessity of adopting a systematic, experimental conditions-specific, validation of references. Journal of experimental botany 2009, 60(2):487-493.

6. Xu Y, Zhu X, Gong Y, Xu L, Wang Y, Liu L: Evaluation of reference genes for gene expression studies in radish (Raphanus sativus L.) using quantitative realtime PCR. Biochemical and biophysical research communications 2012, 424(3):398-403.

7. Niu X, Chen M, Huang X, Chen H, Tao A, Xu J, Qi J: Reference Gene Selection for qRT-PCR Normalization Analysis in kenaf (Hibiscus cannabinus L.) under Abiotic Stress and Hormonal Stimuli. Frontiers in plant science 2017, 8:771.

8. Warzybok A, Migocka M: Reliable reference genes for normalization of gene expression in cucumber grown under different nitrogen nutrition. PloS one 2013, 8(9):e72887.

9. Joseph JT, Poolakkalody NJ, Shah JM: Plant reference genes for development and stress response studies. Journal of biosciences 2018, $43(1): 173-187$.

10. Wan Q, Chen S, Shan Z, Yang Z, Chen L, Zhang C, Yuan S, Hao Q, Zhang X, Qiu D et al: Stability evaluation of reference genes for gene expression analysis by RT-qPCR in soybean under different conditions. 2017, 12(12):e0189405. 
11. Kanakachari M, Solanke AU, Prabhakaran N, Ahmad I, Dhandapani G, Jayabalan N, Kumar PA: Evaluation of Suitable Reference Genes for Normalization of qPCR Gene Expression Studies in Brinjal (Solanum melongena L.) During Fruit Developmental Stages. Applied biochemistry and biotechnology 2016, 178(3):433-450.

12. Wu D, Dong J, Yao YJ, Zhao WC, Gao X: Identification and evaluation of endogenous control genes for use in quantitative RT-PCR during wheat (Triticum aestivum L.) grain filling. Genetics and molecular research : GMR 2015, 14(3):10530-10542.

13. Lin Y, Zhang C, Lan H, Gao S, Liu H, Liu J, Cao M, Pan G, Rong T, Zhang S: Validation of potential reference genes for qPCR in maize across abiotic stresses, hormone treatments, and tissue types. PloS one 2014, 9(5):e95445.

14. Lin F, Jiang L, Liu Y, Lv Y, Dai H, Zhao H: Genome-wide identification of housekeeping genes in maize. Plant molecular biology 2014, 86(4-5):543-554.

15. Ji Y, Tu P, Wang K, Gao F, Yang W, Zhu Y, Li S: Defining reference genes for quantitative real-time PCR analysis of anther development in rice. Acta biochimica et biophysica Sinica 2014, 46(4):305-312.

16. Bevitori R, Oliveira MB, Grossi-de-Sa MF, Lanna AC, da Silveira RD, Petrofeza S: Selection of optimized candidate reference genes for qRT-PCR normalization in rice (Oryza sativa L.) during Magnaporthe oryzae infection and drought. Genetics and molecular research : GMR 2014, 13(4):9795-9805.

17. Dekkers BJ, Willems L, Bassel GW, van Bolderen-Veldkamp RP, Ligterink W, Hilhorst HW, Bentsink L: Identification of reference genes for RT-qPCR expression analysis in Arabidopsis and tomato seeds. Plant \& cell physiology 2012, 53(1):28-37.

18. Kudo T, Sasaki Y, Terashima S, Matsuda-Imai N, Takano T, Saito M, Kanno M, Ozaki S, Suwabe K, Suzuki G et al: Identification of reference genes for quantitative expression analysis using large-scale RNA-seq data of Arabidopsis thaliana and model crop plants. Genes \& genetic systems 2016, 91(2):111125.

19. Tang C, Yang M, Fang Y, Luo Y, Gao S, Xiao X, An Z, Zhou B, Zhang B, Tan X et al: The rubber tree genome reveals new insights into rubber production and species adaptation. 2016, 2(6):16073.

20. Tang C, Huang D, Yang J, Liu S, Sakr S, Li H, Zhou Y, Qin Y: The sucrose transporter HbSUT3 plays an active role in sucrose loading to laticifer and rubber productivity in exploited trees of Hevea brasiliensis (para rubber tree). Plant, cell \& environment 2010, 33(10):1708-1720.

21. Tang C, Xiao X, Li H, Fan Y, Yang J, Qi J, Li H: Comparative analysis of latex transcriptome reveals putative molecular mechanisms underlying super productivity of Hevea brasiliensis. PloS one 2013, 8(9):e75307.

22. Liu S, Lan J, Zhou B, Qin Y, Zhou Y, Xiao X, Yang J, Gou J, Qi J, Huang Y et al: HbNIN2, a cytosolic alkaline/neutral-invertase, is responsible for sucrose catabolism in rubber-producing laticifers of Hevea brasiliensis (para rubber tree). The New phytologist 2015, 206(2):709-725.

23. Chao J, Yang S, Chen Y, Tian WM: Transcript Profiling of Hevea brasiliensis during Latex Flow. Frontiers in plant science $2017,8: 1904$.

24. Liu JP, Hu J, Liu YH, Yang CP, Zhuang YF, Guo XL, Li YJ, Zhang L: Transcriptome analysis of Hevea brasiliensis in response to exogenous methyl jasmonate provides novel insights into regulation of jasmonate-elicited rubber biosynthesis. Physiology and molecular biology of plants : an international journal of functional plant biology 2018, 24(3):349-358.

25. Long X, He B, Fang Y, Tang C: Identification and Characterization of the Glucose-6-Phosphate Dehydrogenase Gene Family in the Para Rubber Tree, Hevea brasiliensis. Frontiers in plant science 2016, 7:215.

26. Li H, Qin Y, Xiao X, Tang C: Screening of valid reference genes for real-time RT-PCR data normalization in Hevea brasiliensis and expression validation of a sucrose transporter gene HbSUT3. Plant science : an international journal of experimental plant biology 2011, 181(2):132-139.

27. Long X, He B, Gao X, Qin Y, Yang J, Fang Y, Qi J, Tang C: Validation of reference genes for quantitative real-time PCR during latex regeneration in rubber tree. Gene 2015, 563(2):190-195.

28. Qin Y, Huang Y, Fang Y, Qi J, Tang C: Molecular characterization and expression analysis of the small GTPase ROP members expressed in laticifers of the rubber tree (Hevea brasiliensis). Plant physiology and biochemistry : PPB 2014, 74:193-204.

29. Chao J, Yang S, Chen Y, Tian WM: Evaluation of Reference Genes for Quantitative Real-Time PCR Analysis of the Gene Expression in Laticifers on the Basis of Latex Flow in Rubber Tree (Hevea brasiliensis Muell. Arg.). Frontiers in plant science 2016, 7:1149.

30. Zhu J, Qi J, Fang Y, Xiao X, Li J, Lan J, Tang C: Characterization of Sugar Contents and Sucrose Metabolizing Enzymes in Developing Leaves of Hevea brasiliensis. Frontiers in plant science 2018, 9:58.

31. Lieberei R: South American leaf blight of the rubber tree (Hevea spp.): new steps in plant domestication using physiological features and molecular markers. Annals of botany 2007, 100(6):1125-1142.

32. Fang Y, Mei H, Zhou B, Xiao X, Yang M, Huang Y, Long X, Hu S, Tang C: De novo Transcriptome Analysis Reveals Distinct Defense Mechanisms by Young and Mature Leaves of Hevea brasiliensis (Para Rubber Tree). Scientific reports 2016, 6:33151. 
33. Huang Y, Fang Y, Long X, Liu L, Wang J, Zhu J, Ma Y, Qin Y, Qi J, Hu X et al: Characterization of the rubber tree metallothionein family reveals a role in mitigating the effects of reactive oxygen species associated with physiological stress. Tree physiology 2018, 38(6):911-924.

34. Pfaffl MW, Tichopad A, Prgomet C, Neuvians TP: Determination of stable housekeeping genes, differentially regulated target genes and sample integrity: BestKeeper-Excel-based tool using pair-wise correlations. Biotechnology letters 2004, 26(6):509-515.

35. Andersen CL, Jensen JL, Orntoft TF: Normalization of real-time quantitative reverse transcription-PCR data: a model-based variance estimation approach to identify genes suited for normalization, applied to bladder and colon cancer data sets. Cancer research 2004, 64(15):5245-5250.

36. Vandesompele J, De Preter K, Pattyn F, Poppe B, Van Roy N, De Paepe A, Speleman F: Accurate normalization of real-time quantitative RT-PCR data by geometric averaging of multiple internal control genes. Genome biology 2002, 3(7):Research0034.

37. Silver N, Best S, Jiang J, Thein SL: Selection of housekeeping genes for gene expression studies in human reticulocytes using real-time PCR. BMC molecular biology 2006, 7:33.

38. Gutierrez L, Mauriat M, Guenin S, Pelloux J, Lefebvre JF, Louvet R, Rusterucci C, Moritz T, Guerineau F, Bellini C et al: The lack of a systematic validation of reference genes: a serious pitfall undervalued in reverse transcription-polymerase chain reaction (RT-PCR) analysis in plants. Plant biotechnology journal 2008, 6(6):609-618.

39. Galeano E, Vasconcelos TS, Ramiro DA, De Martin Vde F, Carrer H: Identification and validation of quantitative real-time reverse transcription PCR reference genes for gene expression analysis in teak (Tectona grandis L.f.). BMC research notes 2014, 7:464.

40. Gill G: SUMO and ubiquitin in the nucleus: different functions, similar mechanisms? Genes \& development 2004, 18(17):2046-2059.

41. Yamao F: Ubiquitin system: selectivity and timing of protein destruction. Journal of biochemistry 1999, 125(2):223-229.

42. Sato T, Maekawa S, Yasuda S, Yamaguchi J: Carbon and nitrogen metabolism regulated by the ubiquitin-proteasome system. Plant signaling \& behavior 2011, 6(10):1465-1468.

43. Ye J, Jin CF, Li N, Liu MH, Fei ZX, Dong LZ, Li L, Li ZQ: Selection of suitable reference genes for qRT-PCR normalisation under different experimental conditions in Eucommia ulmoides Oliv. Scientific reports 2018, 8(1):15043.

44. Liu J, Huang S, Niu X, Chen D, Chen Q, Tian L, Xiao F, Liu Y: Genome-wide identification and validation of new reference genes for transcript normalization in developmental and post-harvested fruits of Actinidia chinensis. Gene 2018, 645:1-6.

45. Pabuayon IM, Yamamoto N, Trinidad JL, Longkumer T, Raorane ML, Kohli A: Reference genes for accurate gene expression analyses across different tissues, developmental stages and genotypes in rice for drought tolerance. Rice (New York, NY) 2016, 9(1):32.

46. Niu L, Tao YB, Chen MS, Fu Q, Li C, Dong Y, Wang X, He H, Xu ZF: Selection of Reliable Reference Genes for Gene Expression Studies of a Promising Oilseed Crop, Plukenetia volubilis, by Real-Time Quantitative PCR. International journal of molecular sciences 2015, 16(6):12513-12530.

47. Storch TT, Pegoraro C, Finatto T, Quecini V, Rombaldi CV, Girardi CL: Identification of a novel reference gene for apple transcriptional profiling under postharvest conditions. PloS one 2015, 10(3):e0120599.

48. Wan H, Yuan W, Ruan M, Ye Q, Wang R, Li Z, Zhou G, Yao Z, Zhao J, Liu S et al: Identification of reference genes for reverse transcription quantitative realtime PCR normalization in pepper (Capsicum annuum L.). Biochemical and biophysical research communications 2011, 416(1-2):24-30.

49. Gu CS, Liu LQ, Xu C, Zhao YH, Zhu XD, Huang SZ: Reference gene selection for quantitative real-time RT-PCR normalization in Iris. lactea var. chinensis roots under cadmium, lead, and salt stress conditions. TheScientificWorldJournal 2014, 2014:532713.

50. Hu Y, Fu H, Qiao H, Sun S: Validation and Evaluation of Reference Genes for Quantitative Real-Time PCR in Macrobrachium Nipponense. 2018, 19(8).

51. Wang M, Wang Q, Zhang B: Evaluation and selection of reliable reference genes for gene expression under abiotic stress in cotton (Gossypium hirsutum L.). Gene 2013, 530(1):44-50.

52. Czechowski T, Stitt M, Altmann T, Udvardi MK, Scheible WR: Genome-wide identification and testing of superior reference genes for transcript normalization in Arabidopsis. Plant physiology 2005, 139(1):5-17.

53. Moraes GP, Benitez LC, do Amaral MN, Vighi IL, Auler PA, da Maia LC, Bianchi VJ, Braga EJ: Evaluation of reference genes for RT-qPCR studies in the leaves of rice seedlings under salt stress. Genetics and molecular research : GMR 2015, 14(1):2384-2398.

54. Xia W, Mason AS, Xiao Y, Liu Z, Yang Y, Lei X, Wu X, Ma Z, Peng M: Analysis of multiple transcriptomes of the African oil palm (Elaeis guineensis) to identify reference genes for RT-qPCR. Journal of biotechnology 2014, 184:63-73.

55. Tang F, Chu L, Shu W, He X, Wang L, Lu M: Selection and validation of reference genes for quantitative expression analysis of miRNAs and mRNAs in Poplar. Plant methods 2019, 15:35. 
56. Chen J, Huang Z, Huang H, Wei S, Liu Y, Jiang C, Zhang J, Zhang C: Selection of relatively exact reference genes for gene expression studies in goosegrass (Eleusine indica) under herbicide stress. Scientific reports 2017, 7:46494.

57. Zhao S, Torres A, Henry RA, Trefely S, Wallace M, Lee JV, Carrer A, Sengupta A, Campbell SL, Kuo YM et al: ATP-Citrate Lyase Controls a Glucose-to-Acetate Metabolic Switch. Cell reports 2016, 17(4):1037-1052.

58. Cheng Y, Pang X, Wan H, Ahammed GJ, Yu J, Yao Z, Ruan M, Ye Q, Li Z, Wang R et al: Identification of Optimal Reference Genes for Normalization of qPCR Analysis during Pepper Fruit Development. Frontiers in plant science 2017, 8:1128.

59. Long XY, Wang JR, Ouellet T, Rocheleau H, Wei YM, Pu ZE, Jiang QT, Lan XJ, Zheng YL: Genome-wide identification and evaluation of novel internal control genes for Q-PCR based transcript normalization in wheat. Plant molecular biology 2010, 74(3):307-311.

\section{Tables}

Table 1 Description of the 24 candidate reference genes, 4 previous reference gens and 2 specific genes 


\begin{tabular}{|c|c|c|c|c|c|}
\hline Gene Name & Gene ID & $\begin{array}{l}\text { Accession } \\
\text { Number }\end{array}$ & Gene Function & Primer Sequence $F\left(5^{\prime}-3^{\prime}\right)$ & Primer Sequence R(5'-3') \\
\hline RG1293 & scaffold1293_128736 & XM_021799024 & $\begin{array}{l}50 \text { S ribosomal } \\
\text { protein L24, } \\
\text { chloroplastic }\end{array}$ & GAATGTAGCAAGTCGGGTGG & TTTCGTGTTCTGCTCTTCCTT \\
\hline RG1039 & scaffold1039_22604 & XM_021794249 & $\begin{array}{l}\text { Splicing factor } 3 B \\
\text { subunit } 4\end{array}$ & ATGGGTCACAATTCAATGGCAT & AGGGGTATGATGTATGGTTAC \\
\hline RG2011 & scaffold2011_47037 & XM_021804641 & $\begin{array}{l}\text { Transcription and } \\
\text { mRNA export factor } \\
\text { SUS1 }\end{array}$ & AAAGACGAAATGAAAGCTCTTTGC & AGGAATAGATGCTCTGCCCTT \\
\hline RG0347 & scaffold0347_1131868 & XM_021827178 & $\begin{array}{l}\text { Transcription } \\
\text { elongation factor } \\
\text { SPT4 homolog } 2\end{array}$ & CGCTGGTTGAGAATCGGAAG & TTGGCGGAATGTATTGTACTC \\
\hline RG1200 & scaffold1200_31568 & XM_021797521 & $\begin{array}{l}\text { Transcription factor } \\
\text { GTE9 }\end{array}$ & ATGGCTTGGGAAGTTTTAAGTTC & TCAАТСААТТТСТСССТСТТС \\
\hline RG0140 & scaffold0140_1151167 & XM_021815322 & $\begin{array}{l}\text { Eukaryotic } \\
\text { translation initiation } \\
\text { factor } 1 \mathrm{~A}\end{array}$ & GGAAGATGCACAAGAAGGTTTGG & TССТCATCAAGACCTCCAGC \\
\hline RG0239 & scaffold0239_1243650 & XM_021821646 & $\begin{array}{l}\text { Pre-rRNA-processing } \\
\text { protein TSR2 } \\
\text { homolog }\end{array}$ & TTAGACAGGCGGCAGATAAC & GTTCACCTGATTTGATTTCGA \\
\hline RG1121 & scaffold1121_251572 & XM_021795919 & $\begin{array}{l}\text { General transcription } \\
\text { factor IIE subunit } 2\end{array}$ & CCACAAACACGGCAAAGAGG & TCTGGAAGATGTGCATTTGTC \\
\hline RG0623 & scaffold0623_52574 & XM_021781311 & $\begin{array}{l}\text { Peptidyl-prolyl cis- } \\
\text { trans isomerase E }\end{array}$ & ACGCATTAAGGGTGGTGAAC & АТстTСстTTTСтсстTСтсG \\
\hline RG1478 & scaffold1478_36769 & XM_021801104 & $\begin{array}{l}\text { Ubiquitin protein } \\
\text { ligase DRIP2 E3 }\end{array}$ & CAGTTTCTCCACAGGCAGATAG & GTAAGAAGCTGCTAAGGGATG \\
\hline RG0520 & scaffold0520_199136 & XM_021835094 & $\begin{array}{l}\text { Ubiquitin-protein } \\
\text { ligase At3g02290 E3 }\end{array}$ & CTGTCCAACATGCCTTGAAGA & GGTGTCACTTCTTTCCATCCA \\
\hline RG0928 & scaffold0928_351560 & XM_021791601 & $\begin{array}{l}\text { Ubiquitin-protein } \\
\text { ligase RING1 E3 }\end{array}$ & ACGATGCTGATTATGAGAGTCGG & AGCTCCACCATCACTGCTAG \\
\hline RG1690 & scaffold1690_30417 & XM_021802842 & $\begin{array}{l}\text { Ubiquitin-protein } \\
\text { ligase RNF170 E3 }\end{array}$ & TGTTCAGAAAGTGCGAGAGTC & CAAACAATCTAACAATCCCCAC \\
\hline RG0470 & scaffold0470_347639 & XM_021833577 & $\begin{array}{l}\text { Ubiquitin- } \\
\text { conjugating enzyme } \\
\text { E2 } 28\end{array}$ & GTAACTAGAAATACACCCCCCG & GCTTCCAAGCGTATTTTGAAG \\
\hline RG0099 & scaffold0099_128107 & XM_021812245 & $\begin{array}{l}\text { Ubiquitin-fold } \\
\text { modifier-conjugating } \\
\text { enzyme } 1\end{array}$ & CCGTTACTTATCCATCTACTGCTC & CAAAGTGGCTTGAAATGAACC \\
\hline RG0354 & scaffold0354_501312 & XM_021827483 & $\begin{array}{l}\text { Ubiquitin-like protein } \\
\text { ATG12 }\end{array}$ & AGCATAATTGACCAGCAGTTTACC & ACTGCCGATGCTCCTATACTC \\
\hline RG2190 & scaffold2190_4544 & XR_002493952 & $\begin{array}{l}\text { F-box protein } \\
\text { SKIP19/Ubiquitin- } \\
\text { protein ligase E3 }\end{array}$ & GTCAATATGGACGGACATTTAGGG & TCAGATGATCCCACGTCAGC \\
\hline RG0782 & scaffold0782_240563 & XM_021787005 & $\begin{array}{l}\text { F-box protein SKIP8/ } \\
\text { Ubiquitin-protein } \\
\text { ligase E3 }\end{array}$ & GCCATTGTGAATGCCAATACAG & CCTTGATCCCAATTAAATGCG \\
\hline RG1376 & scaffold1376_117308 & XM_021800037 & $\begin{array}{l}\text { F-box/LRR-repeat } \\
\text { protein } 14 \text { /Ubiquitin- } \\
\text { protein ligase E3 }\end{array}$ & СTTTGCTCAGCTCCGTATCTG & ACAAGAGGCTTTAACCCATCA \\
\hline RG0118 & scaffold0118_304761 & XM_021814014 & $\begin{array}{l}\text { NEP1-interacting } \\
\text { protein-like 2/ } \\
\text { Ubiquitin-protein } \\
\text { ligase E3 }\end{array}$ & ACCATCTGCTGTACAATATGC & ATGATCCATGTCTTAGGAGCC \\
\hline RG0677 & scaffold0677_270674 & XR_002491008 & $\begin{array}{l}\text { Histone-lysine N- } \\
\text { methyltransferase, } \\
\text { H3 lysine-9 specific } \\
\text { SUVH3 }\end{array}$ & AGAGTTGACTTATGACTATGGGACT & ACCAAAACAACCTCGGCATC \\
\hline RG0544 & scaffold0544_697128 & XM_021836138 & $\begin{array}{l}\text { Pentatricopeptide } \\
\text { repeat-containing } \\
\text { protein (unkown) }\end{array}$ & TGTCTCCTGATAGAAGATGTTGTG & ATGTGCTCTGACAGTTTGTGE \\
\hline RG1206 & scaffold1206_49642 & XM_021797646 & $\begin{array}{l}\text { Protein CURVATURE } \\
\text { THYLAKOID 1A }\end{array}$ & АACTCAGTACCTTTGCTGCC & ATATCTGTTGCTAATTCCTTTC \\
\hline RG0427 & scaffold0427_670390 & XM_021831455 & Bis(5'-adenosyl)- & GCACAGAAAATTGGCAGTCG & ATGTGGATATGAACATGGGGC \\
\hline
\end{tabular}


triphosphatase

\begin{tabular}{|c|c|c|c|c|c|}
\hline elF1Aa & $\begin{array}{l}\text { Previous reference } \\
\text { genes }\end{array}$ & HQ268022 & $\begin{array}{l}\text { Eukaryotictranslation } \\
\text { initiation factor } 1 \mathrm{~A}\end{array}$ & GCGTGACTATCAGGACGACAA & CAAGACCTCCAGCAATACCCT( \\
\hline $\mathrm{RH} 8$ & & HQ323244 & $\begin{array}{l}\text { DEAD/DEAH box } \\
\text { helicase }\end{array}$ & TCACAGGGTTGGTAGATCAG & CCAAGCTCTTGCTCAATCC \\
\hline UBC2A & & HQ323246 & $\begin{array}{l}\text { Ubiquitin-protein } \\
\text { ligase }\end{array}$ & CATTTATGCGGATGGAAGCA & CAGGGGAGTTTGGATTTGGA \\
\hline UBC2B & & HQ323247 & $\begin{array}{l}\text { Ubiquitin-protein } \\
\text { ligase }\end{array}$ & CGACCAAGTTTTCATTTCGGGTG & AGTCTCTTCTTTGCTGGGGTT \\
\hline RG1588154 & Specific genes & XM_021813008 & ATP citrate lyase & CACCAAGTGAGAGAATTGCAGATG & GCCCTCAGCCTATCAACAGTAI \\
\hline RG65560 & & XM_021836811 & ATP citrate lyase & GCCTGAAGCAACAATGACCG & TAGATGGTTATCAGGAGTCAG \\
\hline
\end{tabular}

Table 2 Expression profile of candidate reference genes

\begin{tabular}{|c|c|c|c|c|c|c|c|}
\hline Gene Name & $\mathrm{n}$ & Geo Mean [Ct] & AR Mean [Ct] & $\min [\mathrm{Ct}]$ & $\max [\mathrm{Ct}]$ & std dev $[+/-\mathrm{Ct}]$ & $\mathrm{CV}[\% \mathrm{Ct}]$ \\
\hline RG1293 & 60 & 24.84 & 24.93 & 21.01 & 32.24 & 2.08 & 8.34 \\
\hline RG1039 & 60 & 27.12 & 27.16 & 24.38 & 32.18 & 1.62 & 5.95 \\
\hline RG2011 & 60 & 29.33 & 29.42 & 25.2 & 34.26 & 2.29 & 7.78 \\
\hline RG0347 & 60 & 26.90 & 26.98 & 22.41 & 31.21 & 2.06 & 7.65 \\
\hline RG1200 & 60 & 26.93 & 27.01 & 23.06 & 32.52 & 2.11 & 7.79 \\
\hline RG0140 & 60 & 23.62 & 23.71 & 19.56 & 28.69 & 2.05 & 8.63 \\
\hline RG0239 & 60 & 29.21 & 29.27 & 25.11 & 34.20 & 1.85 & 6.32 \\
\hline RG1121 & 60 & 26.84 & 26.92 & 22.84 & 31.96 & 2.04 & 7.59 \\
\hline RG0623 & 60 & 27.33 & 27.41 & 22.95 & 32.09 & 2.13 & 7.77 \\
\hline RG1478 & 60 & 29.75 & 29.8 & 26.76 & 34.49 & 1.78 & 5.99 \\
\hline RG0520 & 60 & 28.69 & 28.78 & 24.63 & 34.37 & 2.22 & 7.71 \\
\hline RG0928 & 60 & 26.36 & 26.42 & 22.97 & 30.91 & 1.79 & 6.77 \\
\hline RG1690 & 60 & 28.67 & 28.75 & 25.51 & 35.60 & 2.08 & 7.23 \\
\hline RG0470 & 60 & 24.93 & 25.02 & 21.07 & 31.17 & 2.15 & 8.59 \\
\hline RG0099 & 60 & 27.03 & 27.11 & 23.20 & 32.53 & 2.02 & 7.44 \\
\hline RG0354 & 60 & 28.87 & 28.95 & 24.68 & 35.48 & 2.23 & 7.69 \\
\hline RG2190 & 60 & 28.48 & 28.55 & 24.77 & 33.28 & 2.06 & 7.23 \\
\hline RG0782 & 60 & 30.93 & 31.04 & 26.50 & 37.88 & 2.60 & 8.37 \\
\hline RG1376 & 60 & 29.69 & 29.75 & 26.10 & 34.51 & 1.96 & 6.58 \\
\hline RG0118 & 60 & 27.65 & 27.71 & 24.12 & 32.44 & 1.90 & 6.86 \\
\hline RG0677 & 60 & 27.53 & 27.6 & 23.75 & 32.39 & 1.99 & 7.20 \\
\hline RG0544 & 60 & 31.67 & 31.73 & 28.29 & 36.97 & 1.89 & 5.96 \\
\hline RG1206 & 60 & 23.81 & 23.92 & 19.86 & 33.69 & 2.39 & 10.01 \\
\hline RG0427 & 60 & 25.95 & 26.01 & 22.72 & 31.02 & 1.79 & 6.86 \\
\hline eIF1Aa & 60 & 25.94 & 26.03 & 21.54 & 30.83 & 2.18 & 8.39 \\
\hline RH8 & 60 & 27.84 & 27.95 & 23.55 & 34.03 & 2.46 & 8.81 \\
\hline UBC2A & 60 & 26.32 & 26.44 & 21.02 & 31.66 & 2.54 & 9.59 \\
\hline UBC2B & 60 & 26.96 & 27.01 & 23.54 & 30.82 & 1.73 & 6.40 \\
\hline RG1588154 & 60 & 27.95 & 28.12 & 21.79 & 34.20 & 3.01 & 10.72 \\
\hline RG65560 & 60 & 28.84 & 29.03 & 21.81 & 35.09 & 3.24 & 11.15 \\
\hline
\end{tabular}


Table 3 Comprehensive ranking of candidate reference genes according to Delta Ct, Normfinder and Genorm

\begin{tabular}{|c|c|c|c|c|c|}
\hline \multirow[t]{2}{*}{ Gene } & \multicolumn{5}{|c|}{ Ranking of candidate reference genes } \\
\hline & Four experiments & Disease experiment & Low temperature experiment & High temperature experiment & Development experiment \\
\hline RG0099 & 1 & 6 & 3 & 2 & 6 \\
\hline RG0427 & 2 & 15 & 2 & 9 & 3 \\
\hline RG0928 & 3 & 9 & 8 & 7 & 16 \\
\hline RG2190 & 4 & 3 & 12 & 21 & 13 \\
\hline RG0118 & 5 & 5 & 15 & 8 & 12 \\
\hline RG0677 & 6 & 1 & 17 & 23 & 10 \\
\hline eIF1Aa & 7 & 18 & 14 & 20 & 2 \\
\hline RG1121 & 8 & 12 & 5 & 25 & 5 \\
\hline RG0623 & 9 & 4 & 20 & 1 & 23 \\
\hline RG0354 & 10 & 8 & 26 & 17 & 8 \\
\hline RG0347 & 11 & 14 & 25 & 11 & 9 \\
\hline RG0140 & 12 & 20 & 10 & 24 & 7 \\
\hline RG1200 & 13 & 7 & 4 & 26 & 11 \\
\hline RG0520 & 14 & 10 & 27 & 12 & 19 \\
\hline RG0470 & 15 & 29 & 21 & 5 & 14 \\
\hline UBC2B & 16 & 24 & 22 & 13 & 22 \\
\hline RG1039 & 17 & 2 & 6 & 6 & 25 \\
\hline RG1690 & 18 & 22 & 28 & 16 & 17 \\
\hline RG2011 & 19 & 11 & 24 & 18 & 21 \\
\hline UBC2A & 20 & 16 & 1 & 15 & 18 \\
\hline RG1376 & 21 & 26 & 7 & 19 & 24 \\
\hline RG0782 & 22 & 19 & 23 & 28 & 1 \\
\hline RGRH8 & 23 & 13 & 19 & 27 & 4 \\
\hline RG0239 & 24 & 23 & 30 & 29 & 20 \\
\hline RG1293 & 25 & 25 & 9 & 4 & 28 \\
\hline RG1478 & 26 & 28 & 18 & 22 & 26 \\
\hline RG1588154 & 27 & 17 & 11 & 10 & 15 \\
\hline RG0544 & 28 & 27 & 29 & 30 & 27 \\
\hline RG1206 & 29 & 30 & 13 & 3 & 30 \\
\hline RG65560 & 30 & 21 & 16 & 14 & 29 \\
\hline
\end{tabular}

\section{Supplemental File Legends}

Supplemental Table Legends

Table S1 Information of selected 82 candidate reference genes from two transcriptome sequencings

Supplemental Figure Legends

Fig.S1 Expression profile of 82 candidate reference genes under develoment stage and temperture stress of leaf.

Fig.S2 Cluster of four experiments according to ranking of expression stability.

\section{Figures}




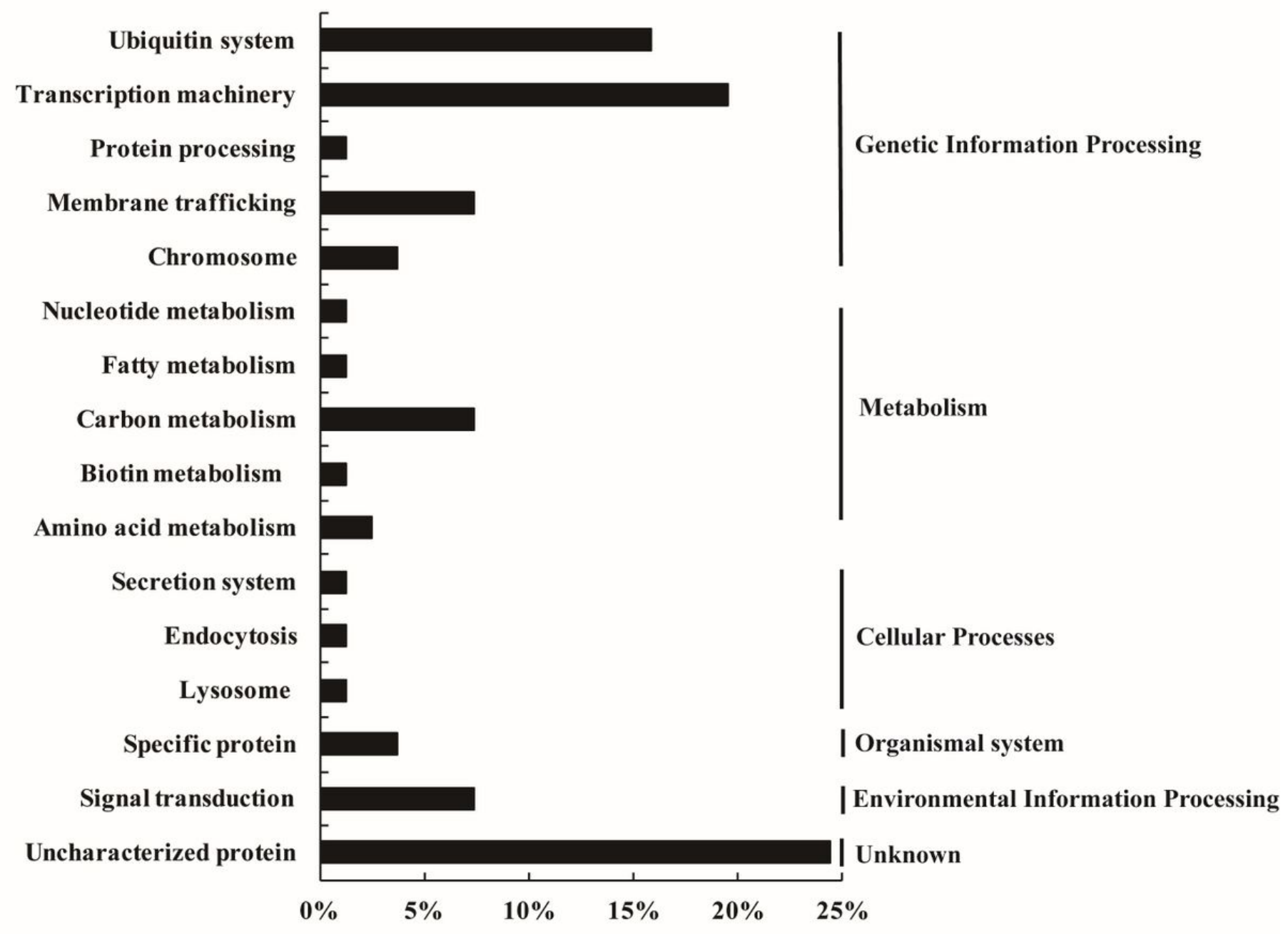

Figure 1

Functional distribution of the 82 candidate reference genes as classified using the KEGG database. 


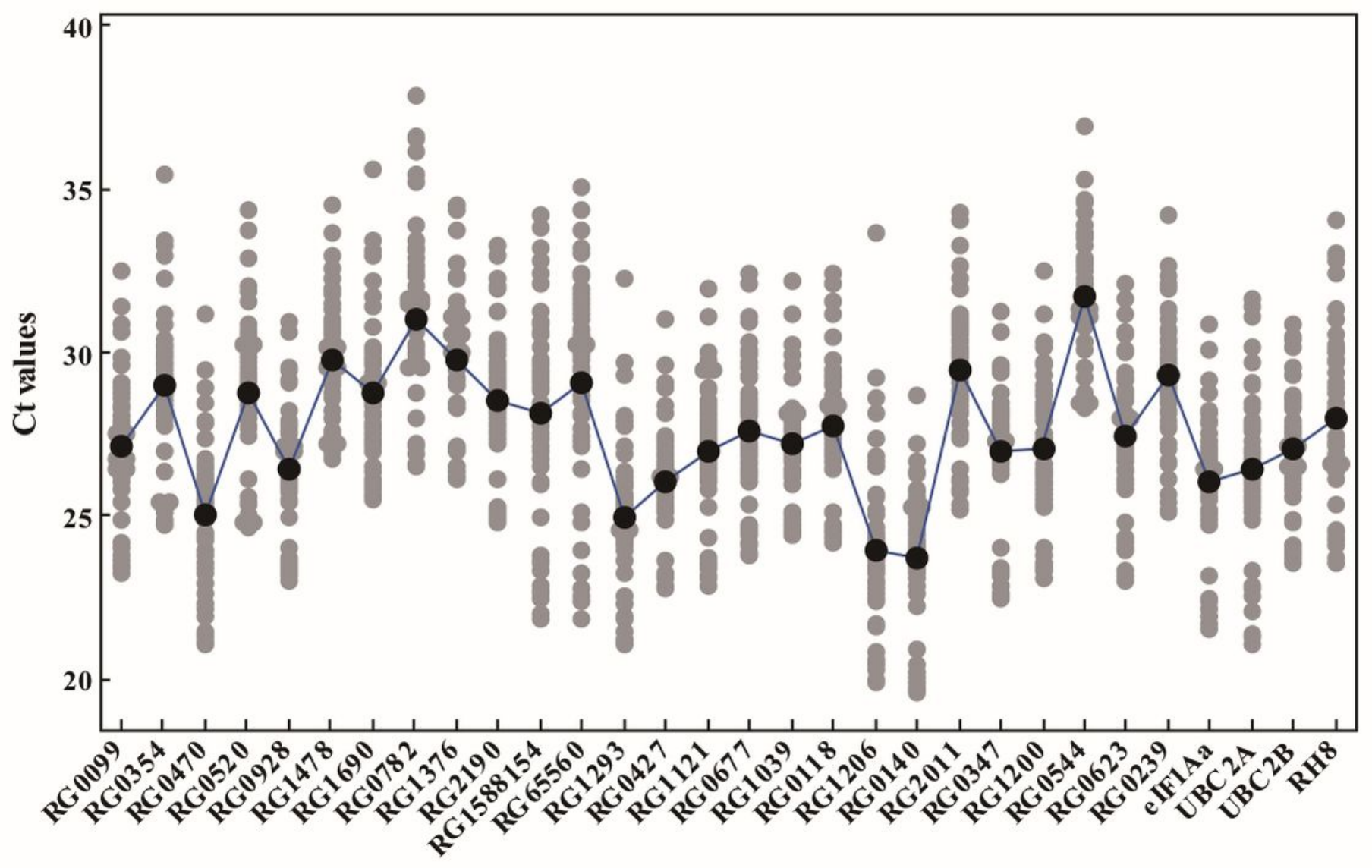

Figure 2

Functional distribution of the 82 candidate reference genes as classified using the KEGG database. 


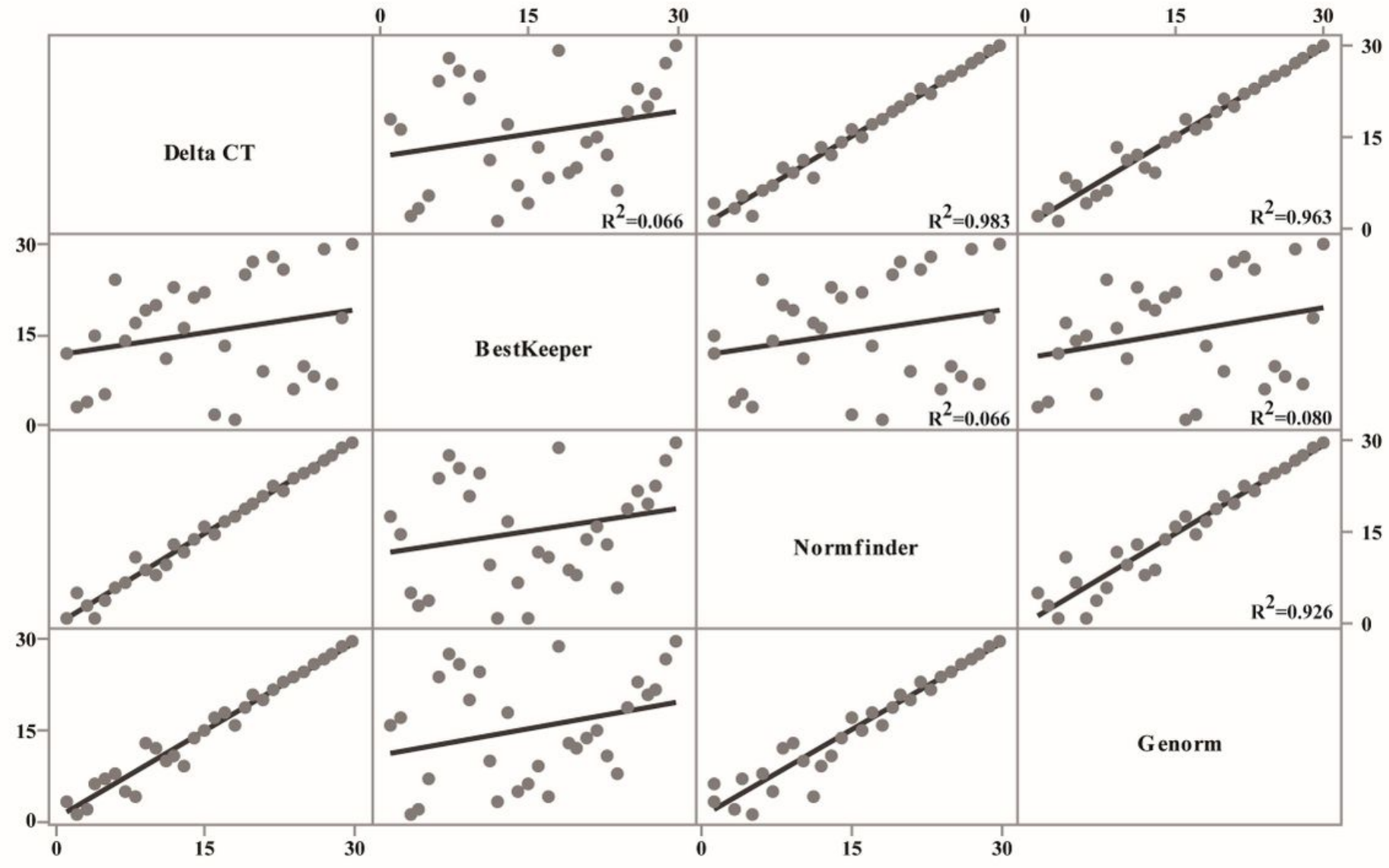

Figure 3

Comparison of the ranking results from Delta Ct, Bestkeeper, NormFinder and GeNorm. The correlation were evaluated for the ranking results of 30 candidate reference genes in all samples, by comparative delta Ct method, Bestkeeper, NormFinder and GeNorm.

A

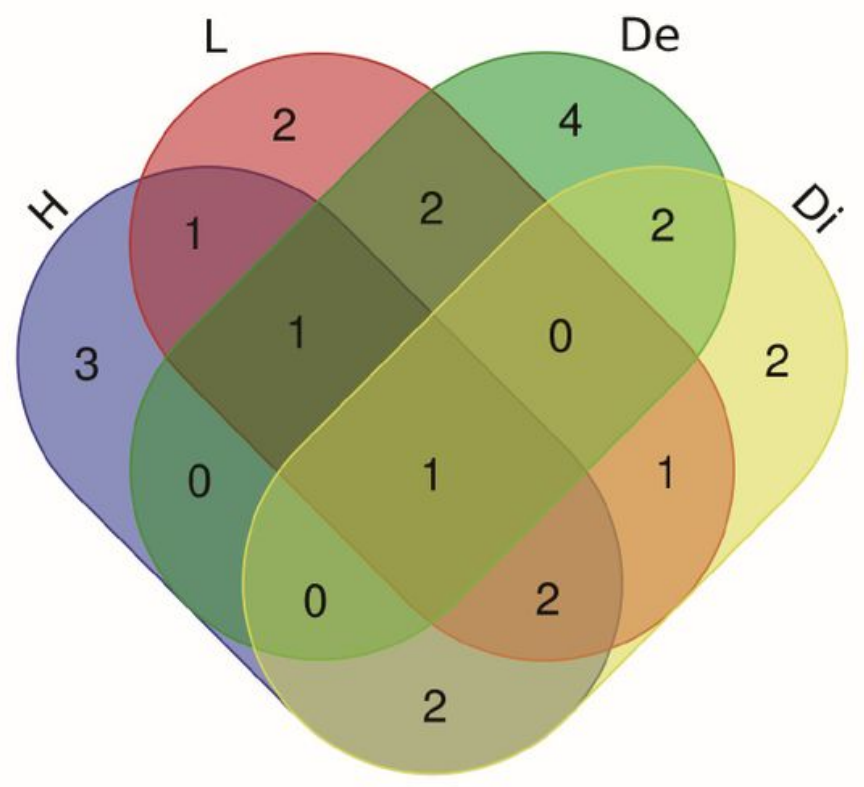

B

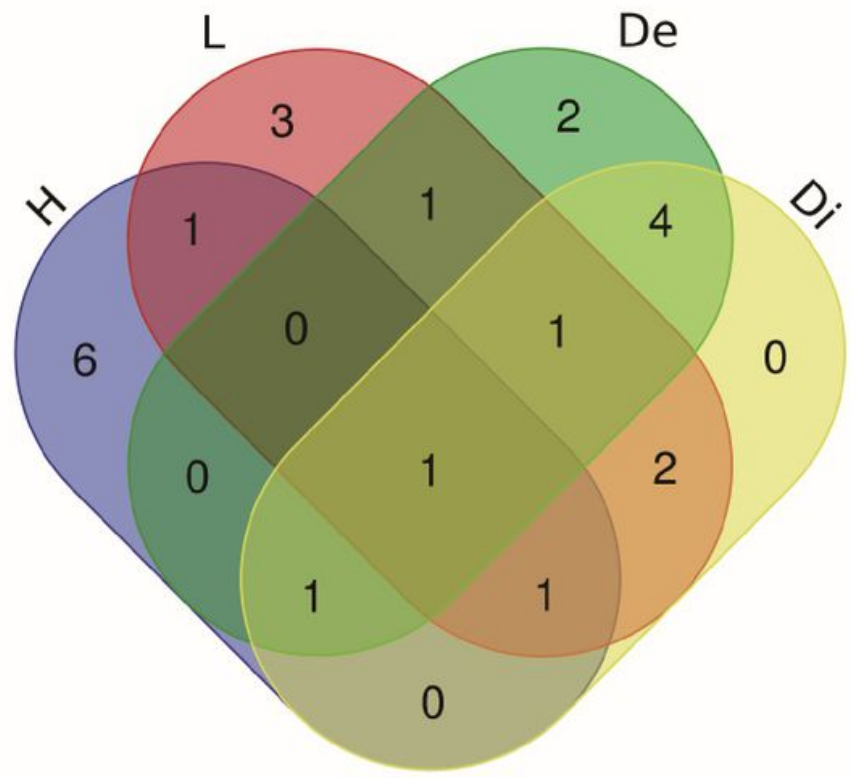

Figure 4 
Venn diagram illustrating shared and unique number of candidate reference genes in four experiments. A. Ten most stable reference genes; B. Ten least stable reference genes; H,high temperature stress;L,low temperature stress;De,developmental stages;Di,disease stress.

\section{Supplementary Files}

This is a list of supplementary files associated with this preprint. Click to download.

- Fig.S1.tif

- Table.S1.xlsx

- Fig.S2.tif 